\title{
Peningkatan Kualitas Jerami Padi MenggunakanTeknologi Amoniasi Fermentasi
}

\section{(Improving the Quality of Rice Straw by Ammoniation-Fermentation Technology)}

\author{
Muhamad Amin, Sofyan Damrah Hasan, Oscar Yanuarianto, Mohammad Iqbal, I Wayan Karda \\ Laboratorium Ilmu Nutrisi dan Makanan Ternak Ruminanasia/Herbivora, Fakultas Peternakan \\ Universitas Mataram \\ Jln. Majapahit 62 Mataram Lombok 83125, Indonesia \\ e-mail: muhamadamin686@yahoo.co.id
}

Diterima: 5 Januari 2016/Disetujui 28 April 2016

\begin{abstract}
An experiment with aim to study the effect of probiotics combination level and length of fermentation on quality improvement of rice straw had been conducted at the Laboratory of Nutrition and Feed of Animal Husbandry Faculty, Mataram University. The research was arranged in a Completely Randomized Design in factorial arrangement $3 \times 3$ with 3 replications. The first factor was the level of probiotics $(0,2$ and $4 \%)$, the second factor was the period of fermentation (2, 4 and 6 weeks).The variables measured were crude protein, crude fiber, NDF, ADF, cellulose, hemicellulose, lignin, and in vitro digestibility of dry matter and organic matter. Data were analyzed by analysis of variance and tested further by Duncan's Multiple Range Test. The result show that treatments combination of the probiotics level and fermentation period did not affect $(\mathrm{P}>0.05)$ the chemical composition and digestibility. The level of probiotics increased $(\mathrm{P}<0.05)$ the crude protein and in vitro dry matter digestibility. Meanwhile, the lenght of fermentation increased the crude protein and in vitro digestibility of dry matter and organic matter, but decreased the crude fiber, NDF, ADF, cellulose, and hemicellulose of Amofer rice straw.
\end{abstract}

Key-words: probiotics, fermentation, quality, rice straw

\section{PENDAHULUAN}

Salah satu faktor penghambat penyediaan hijauan makanan ternak adalah musim. Pada musim hujan produksi hijauan sangat melimpah, sedangkan pada musim kemarau produksi hijauan sangat berkurang sehingga kepentingan pemanfaatan limbah pertanian oleh ternak tidak dapat diabaikan. Jerami padi merupakan salah satu limbah pertanian yang terdapat dalam jumlah yang melimpah dan mudah diperoleh untuk dimanfaatkan sebagai makanan ternak. Karakterisitk jerami padi ditandai oleh rendahnya kandungan nitrogen, kalsium, dan fosfor; sedangkan kandungan serat kasarnya tinggi. Hal ini mengakibatkan daya cerna jerami padi rendah dan konsumsi menjadi terbatas, akan tetapi masih berpotensi sebagai sumber energi (Leng, 1980).

Kecernaan yang rendah pada jerami padi merupakan akibat dari struktur jaringan penyangga tanaman yang sudah tua. Jaringan tanaman ini sudah mengalami proses lignifikasi, sehingga lignoselulosa dan lignohemiselulosa sulit dicerna (Djajane- gara,1983). Lignin merupakan faktor yang lebih banyak mempengaruhi rendahnya daya cerna dari jerami pada umumnya, sedangkan pada jerami padi rendahnya daya cerna disebabkan oleh tingginya kandungan silika. Lignifikasi dan silifikasi bersamasama mempengaruhi rendahnya daya cerna jerami padi (Van Houtert, 1981). Usaha untuk meningkatkan nilai nutrisi dan kecernaan jerami padi dapat dilakukan dengan perlakuan kimia (Amoniasi) dan perlakuan biologis (Probiotik) atau kombinasinya.

Melalui teknologi amoniasi, serat-serat jerami padi menjadi lunak (proses swollen) sehingga serat menjadi lebih mudah untuk disusupi mikroba rumen dan kemudian mudah didegradasi. Oleh sebab itu, terjadinya peningkatan kecernaan jerami padi tidak hanya melalui proses fermentasi oleh mikroba tetapi juga disebabkan oleh proses hidrolisis basa lemah (amoniasi). Melalui proses fermentasi jerami padi dengan EM4, urea juga ditambahkan ke dalamnya sehingga selama proses pemeraman juga terjadi proses amoniasi (Akmal et al., 2004). Pada proses fermentasi dengan Probion, penggunaan urea

http://jurnal.unram.ac.id/ dan jitpi.fpt.unram,ac,id 
dimaksudkan untuk menjadi sumber amonia yang diperlukan untuk pertumbuhan atau perkembangan mikroba dalam proses fermentasi tersebut (Haryanto et al., 2004). Hasil penelitian Prastyawan et al. (2012), bahwa kombinasi perlakuan perbedaan aras starter dan lama peram tidak berpengaruh terhadap peningkatan kecernaan bahan kering, bahan organik dan protein total tongkol jagung. KcBK, KcBO dan protein total meningkat seiring dengan peningkatan aras starter dan lama peram pada masing-masing perlakuan.

Menurut hasil penelitian Sofyan et al. (2010), penambahan probiotik Bacillus sp. dapat meningkatkan kadar protein kasar dan kecernaan in vitro bahan kering dan bahan organik, menurunkan kadar serat kasar, NDF, ADF, selulosa dan lignin jerami padi. Amin et al. (2012), melaporkan bahwa lama waktu fermentasi dapat meningkatkan kadar protein kasar dan kecernaan in vitro bahan kering dan bahan organik; menurunkan kadar serat kasar, NDF, ADF, selulosa dan lignin jerami padi amoniasi yang ditambah probiotik Bacillus $s p$.

AMOFER adalah singkatan dari AMOniasi dan FERmentasi. Dalam AMOFER ini dikenal dua proses. Proses yang pertama adalah Amoniasi yaitu suatu cara pengolahan jerami padi dengan menggunakan urea. Dalam proses amoniasi, amoniak berperan untuk menghidrolisis ikatan lignin selulosa, menghancurkan ikatan lignin hemiselulosa dan memuaikan serat selulosa sehingga memudahkan penetrasi enzim selulase dan meningkatkan kadar nitrogen sehingga kandungan protein kasar meningkat (Komar, 1984). Proses yang ke dua adalah fermentasi yaitu suatu proses an-aerob dengan memanfaatkan campuran beberapa bakteri seperti proteolitik, selulotik, lipolitik dan lignolitik. Melalui teknologi AMOFER ini dapat meningkatkan nilai gizi dan kecernaan jerami padi yang pada akhinya dapat meningkatkan produktivitas ternak.

Berdasarkan uraian di atas maka perlu dilakukan penelitian untuk mengetahui pengaruh aras probiotik, lama fermentasi dan kombinasinya terhadap komposisi kimia dan kecernaan jerami padi.

\section{MATERI DAN METODE}

\section{Lokasi dan waktu penelitian}

Penelitian dilaksanakan di Laboratorium Ilmu Nutrisi dan Makanan Ternak dan Laboratorium Terapan Fakultas Peternakan Universitas Mataram.
Penelitian dilaksanakan selama enam bulan, dimulai dari bulan Juni sampai Desember 2013.

\section{Bahan dan alat penelitian}

Bahan yang digunakan dalam penelitian ini adalah jerami padi, urea, probiotik dan kantong plastik. Alat penelitian terdiri dari rak fermentasi dan seperangkat alat untuk analisis proksimat, seperangkat alat untuk analisis Serat dan seperangkat alat untuk analisis kecernaan in vitro jerami padi.

\section{Prosedur pelaksanaan penelitian}

Kegiatan penelitian ini terbagi dalam tiga tahap, yaitu tahap persiapan, tahap pembuatan jerami padi Amofer dan tahap Analisis Laboratorium. Tahap persiapan meliputi pengadaan jerami padi, urea, probiotik Bacillus sp. dan kantong plastik. Tahap pembuatan: jerami padi dijemur di bawah sinar matahari dan dipotong-potong dengan ukuran $5 \mathrm{~cm}$. Jerami padi diambil $250 \mathrm{~g}$ dan dicampur dengan urea $4 \%$ dan probiotik Bacillus sp. $(0,2$, dan $4 \%$ dari BK jerami padi) kemudian dimasukkan ke dalam 27 kantong plastik (tiap-tiap kantong plastik berisi $250 \mathrm{~g}$ jerami padi perlakuan) kemudian disimpan di dalam ruang fermentasi selama 2, 4, dan 6 minggu. Tahap analisis: jerami padi fermentasi tersebut diambil dan dijemur sampai berat konstan lalu digiling dan disaring dengan saringan yang berdiameter lubang ayakan $1 \mathrm{~mm}$ yang selanjutnya dianalisis komposisi kimia dan kecernaan in vitro sesuai metode AOAC (1970).

\section{Perlakuan}

Penelitian ini dirancang menggunakan Rancangan Acak Lengkap pola Faktorial 3 x 3 , yaitu 3 perlakuan level probiotik (P), yaitu $\mathrm{P} 1=0 \%, \mathrm{P} 2=2 \%$, dan $\mathrm{P} 3=4 \%$, serta 3 perlakuan lama fermentasi $(\mathrm{F})$, yaitu $\mathrm{F} 1=2$ minggu, $\mathrm{F} 2=4$ minggu dan $\mathrm{F} 3=6$ minggu. Masing-masing perlakuan di masingmasing faktor diulang $3 \mathrm{kali}$, sehingga penelitian ini menggunakan 27 kantong jerami.

\section{Variabel yang diamati}

Beberapa variabel yang diamati untuk mengetahui pengaruh kombinasi perlakuan terhadap kualitas jerami padi, adalah: protein kasar, serat kasar, neutral detergent fibre (NDF), acid detergent fibre (ADF), selulosa, lignin, kecernaan in vitro bahan kering dan bahan organik.

\section{Analisis data}

Muhamad Amin, Sofyan Damrah Hasan, Oscar Yanuarianto, Mohammad Iqbal, I Wayan Karda (Peningkatan Kualitas Jerami ........) 
Data yang diperoleh dari hasil percobaan ini dianalisis menggunakan analisa varian dan uji lanjut Uji Jarak Berganda Duncan's (Steel dan Torrie, 1980).

\section{HASIL DAN PEMBAHASAN}

\section{Pengaruh aras probiotik dan lama fermentasi terhadap komposisi kimia jerami padi amofer}

Hasil penelitian tentang pengaruh aras probiotik dan lama fermentasi terhadap kandungan protein kasar dan serat kasar jerami padi Amofer disajikan pada Tabel 1.

Tabel 1. Pengaruh aras probiotik dan lama fermentasi terhadap kandungan protein kasar dan serat kasar jerami padi amofer

\begin{tabular}{lllll}
\hline \multicolumn{1}{c}{ Perlakuan } & F1 & F2 & F3 & Rerata \\
\hline Protein Kasar & 10,304 & 11,950 & 11,444 & $11,233^{\mathrm{b}}$ \\
P1 & 11,157 & 12,522 & 15,021 & $12,901^{\mathrm{a}}$ \\
P2 & 10,894 & 12,564 & 13,156 & $12,205^{\mathrm{a}}$ \\
P3 & $10,785^{\mathrm{b}}$ & $12,345^{\mathrm{a}}$ & $13,207^{\mathrm{a}}$ & \\
\hline Rerata & & & & \\
\hline Serat Kasar & 32,145 & 31,342 & 29,184 & 30,890 \\
P1 & 31,426 & 31,257 & 30,353 & 31,009 \\
P2 & 30,883 & 31,560 & 29,525 & 30,580 \\
P3 & $31,481^{\mathrm{a}}$ & $31,386^{\mathrm{a}}$ & $29,687^{\mathrm{b}}$ & \\
\hline Rerata & & & & \\
\hline
\end{tabular}

Keterangan: Superskrip yang berbeda pada baris dan kolom yang sama menunjukkan perbedaan nyata $(\mathrm{P}<0,05)$. $\mathrm{P} 1$ :

kontrol, $\mathrm{P} 2=2 \%$ probiotik, $\mathrm{P} 3=4 \%$ probiotik. $\mathrm{F} 1=2$ minggu, $\mathrm{F} 2=4$ minggu, $\mathrm{F} 3=6$ minggu

Hasil analisis keragamam menunjukkan bahwa kombinasi perlakuan aras probiotik dan lama fermentasi tidak berinteraksi dalam mempengaruhi kandungan protein kasar dan serat kasar. Aras probiotik berpengaruh nyata $(\mathrm{P}<0,05)$ terhadap protein kasar, tetapi tidak terhadap serat kasar. Lama fermentasi berpengaruh nyata $(\mathrm{P}<0,05)$ terhadap protein kasar dan serat kasar (Tabel 1).

Hasil Uji Jarak Berganda Duncan's menunjukkan bahwa perlakuan aras probiotik P2 (2\%) memberikan kandungan protein kasar yang nyata $(\mathrm{P}<0.05)$ lebih tinggi bila dibandingkan dengan $\mathrm{P} 1$, tetapi tidak berbeda dengan P3. Kandungan protein kasar pada $\mathrm{P} 3$ nyata $(\mathrm{P}<0,05)$ lebih tinngi dari pada $\mathrm{P} 1$. Tingginya kandungan protein kasar ini diduga erat kaitannya dengan adanya perbedaan penambahan aras probiotik. Peningkatan protein kasar seiring dengan semakin tingginya aras probiotik yang digunakan dalam penelitian. Kandungan protein kasar $(13,207 \%)$ jerami padi Amofer yang diperam selama 6 minggu (F3) nyata $(\mathrm{P}<0,05)$ lebih tinggi dari pada yang diperam selama 2 minggu (F1). Kandungan protein kasar antara perlakuan F1 dan F2 tidak berbeda. Tingginya kandungan protein kasar pada perlakuan F3 ini disebabkan karena perbedaan lama waktu fermentasi; semakin lama waktu fermentasi maka semakin banyak fiksasi nitrogen dari ammonia yang terbentuk oleh jerami padi. Proses amoniasi akan menyebabkan terjadinya fiksasi nitrogen $(\mathrm{N})$ ke dalam jaringan jerami padi dan nitrogen yang terfiksasi ini nantinya akan terukur sebagai protein kasar. Menurut Komar (1984), kenaikan kadar protein kasar yang diamoniasi dengan urea adalah sebagai akibat dari adanya ammonia hasil hidrolisis urea yang terfiksasi ke dalam jaringan serat dan nitrogen yang terfiksasi akan terukur sebagai protein kasar.

Kandungan serat kasar jerami padi yang diperam 6 minggu nyata $(\mathrm{P}<0,05)$ lebih rendah bila dibandingkan dengan yang diperam 2 dan 4 minggu (Tabel 1). Serat kasar jerami padi yang diperam 2 dan 4 minggu tidak berbeda. Rendahnya kandungan serat kasar $(29,687 \%$ ) pada perlakuan F3 (diperam 6 minggu) disebabkan oleh perbedaan lama waktu fermentasi. Rataan serat kasar secara keseluruhan mengalami penurunan sejalan dengan semakin lamanya waktu fermentasi. Waktu fermentasi yang 
singkat mengakibatkan terbatasnya kesempatan dari mikroorganisme untuk terus berkembang sehingga komponen substrat yang dapat dirombak menjadi massa sel juga akan sedikit, tetapi dengan waktu yang lebih lama berarti memberi kesempatan bagi mikroorganisme untuk tumbuh dan berkembang biak (Fardiaz, 1992). Semakin lama waktu fermentasi maka semakin banyak zat makanan yang dirombak seperti bahan kering dan bahan organik. Menurut Judoamidjoj et al. (1989), mikroba yang dimasukkan ke dalam medium baru tidak akan segera tumbuh dan waktu generasinya masih lambat, hal ini tergantung spesies dan umur mikroba, substrat serta faktor lingkungan pertumbuhan. Peningkatan lama fermentasi menyebabkan meningkatnya kesempatan mikroba untuk melakukan petrumbuhan dan fermentasi sehingga semakin lama fermentasi maka kesempatan untuk mendegradasi jerami padi semakin tinggi. Dengan demikian semakin lama fermentasi maka serat kasar jerami padi semakin menurun. Penurunan serat kasar jerami padi ini juga terjadi oleh karena adanya proses amoniasi pada jerami padi yang dapat menyebabkan perubahan sruktur dinding sel. Perubahan stuktur dinding sel ini disebabkan oleh adanya proses hidrolisis dari urea yang mampu memecah ikatan lignoselulosa dan lignohemiselulosa serta melarutkan silika dan lignin yang terdapat dalam dinding sel bahan pakan berserat (Komar, 1984).

\section{Pengaruh aras probiotik dan lama fermentasi terhadap komponen serat jerami padi}

Hasil penelitian tentang pengaruh aras probiotik dan lama fermentasi terhadap kandungan NDF, ADF, Hemiselulosa, Selulosa dan Lignin jerami padi Amofer dapat dilihat pada Tabel 2.

Hasil analisis keragamam menunjukkan bahwa aras probiotik tidak mempengaruhi kandungan komponen serat jerami padi Amofer. Lama fermentasi berpengaruh nyata $(\mathrm{P}<0,05)$ terhadap kandungan komponen serat (Tabel 2).

Berdasarkan hasil Uji jarak Berganda Duncan's bahwa rataan NDF pada lama fermentasi 6 minggu (F3) nyata $(\mathrm{P}<0,05)$ lebih rendah dibandingkan dengan lama fermentasi 2 dan 4 minggu. Hasil penelitian menunjukkan bahwa rataan NDF ada kecenderungan menurun seiring dengan meningkatnya lama waktu fermentasi. Fermentasi berjalan akibat adanya aktivitas mikroorganisme yang menghasilkan enzim selulase yang berfungsi untuk menguraikan senyawa kompleks dari substratnya. Menurut Judoamidjaja et al. (1989), mikroba yang dimasukkan ke dalam medium baru, tidak akan segera tumbuh dan waktu generasinya lambat, hal ini tergantung spesies dan umur mikroba, substrat serta faktor lingkungan pertumbuhan. Peningkatan lama fermentasi menyebabkan meningkatnya kesempatan mikroba untuk melakukan pertumbuhan dan fermentasi, sehingga semakin lama waktu fermentasi maka kesempatan mikroba untuk mendegradasi jerami padi semakin tinggi.

Rataan kandungan NDF terendah diperoleh pada F3 (6 minggu) yaitu sebesar $69,746 \%$. Rendahnya kandungan NDF juga disebabkan oleh adanya perlakuan amoniasi pada jerami padi yang berakibat terjadinya pemutusan ikatan antara lignin dengan polisakarida penyusun dinding sel yang pada gilirannya akan meningkatkan hemiselulosa dan atau selulosa atau terjadi penurunan kandungan hemiselulosa dan selulosa jerami padi. Pada akhirnya penurunan kedua fraksi tersebut akan berakibat pada penurunan kandungan NDF jerami padi. Dengan adanya penurunan kandungan NDF jerami padi maka peluang mikroba rumen untuk memecahkan komponen serat jerami padi semakin besar dan pada gilirannya akan meningkatkan jumlah bahan yang dapat dicerna oleh mikroorganisme rumen sehingga energi yang tersedia bagi ternak meningkat.

Berdasarkan hasil Uji Jarak Berganda Duncan's bahwa rataan kandungan $\mathrm{ADF}$ terendah diperoleh pada F3 yaitu sebesar $52,899 \%$ berbeda nyata $(\mathrm{P}<0,05)$ bila dibandingkan dengan $\mathrm{F} 1$ dan $\mathrm{F} 2$ (Tabel 2). Rataan ADF pada F1 dan F2 tidak berbeda. Hasil penelitian ini menunjukkan bahwa rataan kandungan $\mathrm{ADF}$ menurun seiring dengan meningkatnya lama waktu fermentasi.

Penurunan rataan kandungan ADF pada lama fermentasi 6 minggu (F3) diduga telah terjadi perombakan dinding sel selama proses fermentasi. Terlarutnya sebagian protein dinding sel dan hemiselulosa dalam larutan deterjen asam, sehingga meningkatkan porsi ADS dan menyebabkan menurunnya kandungan ADF. Tanuwijaya (1987) menyatakan bahwa degradasi secara biologis pada saat proses fermentasi merupakan salah satu cara mengubah bahan yang mengandung komponen serat seperti selulosa dan lignin menjadi bahan berguna seperti monosakarida, disakarida atau selobiosa.

Perbedaan rataan kandungan ADF disebabakan karena penambahan urea pada perlakuan fermentasi dapat melonggarkan ikatan lignoselulosa sehingga 
Jurnal Ilmu dan Teknologi Peternakan Indonesia

mudah dicerna oleh enzim yang disekresikan oleh

dan serat kasar menurun sehingga kandungan ADF bakteri yang menyebabkan kandungan bahan kering

Tabel 2. Pengaruh aras probiotik dan lama fermentasi terhadap kandungan NDF, ADF, hemiselulosa, selulosa dan liginin jerami padi amofer

\begin{tabular}{|c|c|c|c|c|}
\hline Perlakuan & F1 & $\mathrm{F} 2$ & $\mathrm{~F} 3$ & Rerata \\
\hline \multicolumn{5}{|l|}{ NDF } \\
\hline $\mathrm{P} 1$ & 72,737 & 74,054 & 69,528 & 72,106 \\
\hline $\mathrm{P} 2$ & 72,495 & 74,501 & 70,565 & 72,521 \\
\hline P3 & 73,202 & 74,204 & 69,144 & 72,183 \\
\hline Rerata & $72,805^{\mathrm{b}}$ & $74,257^{\mathrm{a}}$ & $69,745^{\mathrm{c}}$ & \\
\hline \multicolumn{5}{|l|}{ A D F } \\
\hline $\mathrm{P} 1$ & 56,404 & 55,665 & 52,552 & 54,874 \\
\hline $\mathrm{P} 2$ & 55,540 & 55,785 & 53,127 & 54,818 \\
\hline P3 & 55,990 & 54,937 & 53,017 & 54,648 \\
\hline Rerata & $55,978^{\mathrm{a}}$ & $55,462^{\mathrm{a}}$ & $52,899^{b}$ & \\
\hline \multicolumn{5}{|l|}{ Hemiselulosa } \\
\hline $\mathrm{P} 1$ & 16,332 & 18,388 & 16,653 & 17,124 \\
\hline $\mathrm{P} 2$ & 16,843 & 18,716 & 17,614 & 17,724 \\
\hline P3 & 18,543 & 19,267 & 16,147 & 17,985 \\
\hline Rerata & $17,239^{b}$ & $18,790^{\mathrm{a}}$ & $16,804^{b}$ & \\
\hline \multicolumn{5}{|l|}{ Selulosa } \\
\hline $\mathrm{P} 1$ & 34,467 & 34,815 & 30,511 & 33,264 \\
\hline $\mathrm{P} 2$ & 35,370 & 33,839 & 31,399 & 33,536 \\
\hline P3 & 33,619 & 34,484 & 30,991 & 33,031 \\
\hline Rerata & $34,485^{\mathrm{a}}$ & $34,379^{\mathrm{a}}$ & $30,967^{b}$ & \\
\hline \multicolumn{5}{|l|}{ L i g n i n } \\
\hline $\mathrm{P} 1$ & 3,839 & 3,392 & 4,372 & 3,867 \\
\hline $\mathrm{P} 2$ & 2,962 & 4,031 & 4,64 & 3,879 \\
\hline P3 & 3,484 & 4,075 & 5,411 & 4,323 \\
\hline Rerata & $3,428^{b}$ & 3,8331 & $4,809^{\mathrm{a}}$ & \\
\hline
\end{tabular}

Keterangan: Superskrip yang berbeda pada baris dan kolom yang sama menunjukkan perbedaan nyata $(\mathrm{P}<0,05)$.

$\mathrm{P} 1$ : kontrol, $\mathrm{P} 2=2 \%$ probiotik, $\mathrm{P} 3=4 \%$ probiotik. $\mathrm{F} 1=2$ minggu, $\mathrm{F} 2=4$ minggu, $\mathrm{F} 3=6$ minggu. $\mathrm{NDF}=$ neutral detergent fibre, $\mathrm{ADF}=$ acid detergent fibre

menurun. Hal ini sesuai dengan pendapat Sundstol dan Owen (1984) yang mengatakan bahwa urea dapat melonggarkan ikatan lignoselulosa sehingga membengkak dan bagian kristal berkurang. Hal ini memudahkan penetrasi enzim yang dihasilkan oleh bakteri dan jamur sehingga akibatnya akan meningkatkan kecernaan bahan kering, bahan organik, dinding sel dan TDN.

Berdasarkan hasil analisis keragaman dapat diketahui bahwa lama fermentasi nyata $(\mathrm{P}<0,05)$ mempengaruhi kandungan hemiselulosa, selulosa dan lignin, sedangkan aras probiotik tidak (Tabel 2). Hasil Uji Jarak Berganda Duncan's memperlihatkan bahwa lama fermentasi 6 minggu (F3) memberikan kandungan hemiselulosa yang berbeda nyata $(\mathrm{P}<0,05)$ lebih rendah bila dibandingkan dengan lama fermentasi 4 minggu, tetapi tidak berbeda dengan lama fermentasi 2 minggu. Rataan kandungan selulosa 30,967\% dengan lama fermentasi 6 minggu nyata $(\mathrm{P}<0,05)$ lebih rendah dari pada lama fermentasi 2 dan 4 minggu $(34,485 \%$ dan $34,379 \%)$, tetapi antara $\mathrm{F} 1$ 
dan F2 tidak berbeda. Kandungan lignin dengan lama waktu fermentasi 2 minggu nyata $(\mathrm{P}<0,05)$ lebih rendah dari pada waktu fermentasi 6 minggu (Tabel 2), namun tidak berbeda dengan kandungan lignin pada lama waktu fermentasi 4 minggu. Kecuali kandungan lignin, hasil penelitian terhadap rataan kandungan hemiselulosa dan selulosa menurun seiring dengan meningkatnya lama waktu fermentasi.

Pada prinsipnya daya kerja alkali adalah memutuskan sebagian ikatan antara selulosa dan hemiselulosa dengan lignin dan silika, merombak struktur dinding sel melalui pengembangan jaringan serat yang pada gilirannya memudahkan penetrasi enzim mikroorganisme (Komar, 1984). Selanjutnya Sungkono (1999) menyatakan bahwa perlakuan alkali dapat melarutkan lignin dan selulosa jerami padi.

\section{Pengaruh aras probiotik dan lama fermentasi terhadap kecernaan bahan kering dan bahan organik jerami padi amofer}

Hasil penelitian tentang pengaruh aras probiotik dan lama fermentasi terhadap kecernaan bahan kering dan bahan organik tertera pada Tabel 3 .

Hasil analisis keragaman menunjukkan bahwa aras probiotik dan lama fermentasi nyata $(\mathrm{P}<0,05)$ mempengaruhi kecernaan bahan kering (KCBK), sedangkan kecernaan bahan organik (KCBO) hanya dipengaruhi oleh lama fermentasi.

Tabel 3. Pengaruh aras probiotik dan lama pemeraman terhadap kecernaan kering dan bahan organik jerami padi amofer

\begin{tabular}{lllll}
\hline \multicolumn{1}{c}{ Perlakuan } & F1 & F2 & F3 & Rerata \\
\hline KCBK & 45,770 & 49,251 & 50,270 & $48,430^{\mathrm{b}}$ \\
P1 & 47,906 & 49,676 & 51,464 & $49,682^{\mathrm{a}}$ \\
P2 & 49,206 & 50,777 & 50,458 & $50,147^{\mathrm{a}}$ \\
P3 & $47,627^{\mathrm{b}}$ & $49,902^{\mathrm{a}}$ & $50,731^{\mathrm{a}}$ & \\
\hline Rerata & 52,863 & 53,380 & 56,000 & 54,081 \\
KCBO & 53,641 & 54,112 & 58,539 & 55,430 \\
P1 & 53,452 & 57,668 & 56,700 & 55,940 \\
P2 & $53,319^{\mathrm{b}}$ & $55,053^{\text {ba }}$ & $57,080^{\mathrm{a}}$ & \\
P3 & & & & \\
\hline Rerata & &
\end{tabular}

Keterangan: Superskrip yang berbeda pada baris dan kolom yang sama menunjukkan perbedaan nyata $(\mathrm{P}<0,05)$.

$\mathrm{P} 1$ : kontrol, $\mathrm{P} 2=2 \%$ probiotik, $\mathrm{P} 3=4 \%$ probiotik. $\mathrm{F} 1=2$ minggu, $\mathrm{F} 2=4$ minggu, $\mathrm{F} 3=6$ minggu. $\mathrm{KCBK}=$ kecernaan

bahan kering, $\mathrm{KCBO}=$ kecernaan bahan organic.

Berdasarkan hasil Uji Jarak Berganda Duncan's bahwa KCBK pada perlakuan aras probiotik 4\% (3) nyata lebih tinggi dibandingkan dengan perlakuan aras probiotik $0 \%(\mathrm{P} 1)$, tetapi tidak berbeda dengan perlakuan aras probiotik 2\% (P2). Tingginya kandungan KCBK ini diduga erat kaitannya dengan adanya perbedaan penambahan aras probiotik. Peningkatan kandungan KCBK ini seiring dengan semakin tingginya aras probiotik yang digunakan dalam penelitian. Lama waktu fermentasi 6 minggu (F3) nyata $(\mathrm{P}<0,05)$ lebih tinggi kandungan KCBK dari pada lama fermentasi 2 minggu (F1), namun tidak berbeda dengan lama fermentasi 4 minggu (F2). Hasil penelitian ini menunjukkan bahwa rataan
KCBK meningkat seiring dengan meningkatnya lama waktu fermentasi. Peningkatan lama waktu fermentasi sampai 6 minggu sudah cukup tinggi untuk meningkatkan KCBK hingga mencapai 50,08\%. Menurut Judoamidjojo et al. (1989), mikroba yang dimasukkan ke dalam medium baru, tidak akan segera tumbuh dan waktu generasinya lambat, hal ini tergantung spesies dan umur mikroba, substrat serta faktor lingkungan partumbuhan. Peningkatan lama waktu fermentasi menyebabkan meningkatnya kesempatan mikroba untuk melakukan pertumbuhan dan fermentasi, sehingga semakin lama waktu fermentasi maka

Muhamad Amin, Sofyan Damrah Hasan, Oscar Yanuarianto, Mohammad Iqbal, I Wayan Karda (Peningkatan Kualitas Jerami .......) 
kesempatan mikroba untuk mendegradasi jerami padi semakin meningkat.

Hasil Uji Jarak Berganda Duncan's menunjukkan bahwa KCBO pada perlakuan lama fermentasi 6 minggu (F3) nyata lebih tinggi dibandingkan dengan perlakuan lama fermentasi 2 minggu, tetapi tidak berbeda dengan lama fermentasi 4 minggu (Tabel 3). Hasil penelitian ini secara keseluruhan memperlihatkan bahwa semakin lama waktu fermentasi maka kecernaan bahan organik jerami padi semakin tinggi. Hal ini dapat terjadi karena pada awal-awal fermentasi, pertumbuhan mikroba masih belum optimal sehingga degradasi serat belum optimal, akibatnya kecernaan juga tidak maksimal.

Dalam pelaksanaan fermentasi, lama waktu fermentasi merupakan salah satu faktor yang harus diperhatikan. Lama waktu fermentasi yang singkat mengakibatkan terbatasnya kesempatan dari mikroorganisme untuk terus berkembang, sehingga komponen substrat yang dapat dirombak menjadi massa sel juga akan sedikit, tetapi dengan waktu yang lebih lama berarti memberi kesemptan bagi mikroorganisme untuk tumbuh dan berkembang biak (Fardiaz, 1992).

\section{SIMPULAN DAN SARAN}

\section{Simpulan}

Hasil penelitian menunjukkan bahwa perlakauan kombinasi aras probiotik dan lama waktu fermentasi tidak berpengaruh terhadap komposisi kimia dan kecernaan jerami padi Amofer. Perlakuan aras probiotik hanya dapat meningkatkan kandungan protein kasar dan kecernaan in vitro bahan kering. Sedangkan lama waktu fermentasi dapat meningkatkan kandungan protein kasar, kecernaan in vitro bahan kering dan bahan organik; tetapi menurunkan kandungan serat kasar, selulosa, hemiselulosa, NDF dan ADF jerami padi Amofer.

\section{Saran}

Untuk mengetahui pengaruh jerami padi Amofer terhadap produktivitas ternak, maka perlu dilakukan penelitian lebih lanjut mengenai penggunanaan jerami padi Amofer pada ternak ruminansia.

\section{DAFTAR PUSTAKA}

Akmal, J. Andayani dan Novianti., 2004. Evaluasi perubahan kandungan NDF, ADF dan hemiselulosa pada jerami padi yang difermentasi dengan menggunakan EM4. Jurnal Ilmiah IlmuIlmu Peternakan. 7(3): 168:173.

Amin, M., Sofyan, D.H., Oscar,Y. dan M. Iqbal., 2012. Pengaruh lama fermentasi terhadap peningkatan kualitas jerami padi amoniasi yang ditambah probiotik Bacillus sp. Laporan Penelitian Fakultas Peternakan Universitas Mataram, Mataram.

AOAC. 1970. Official Methods of Analysis of the Association of Official Agricultural Chemists. Washington DC, USA.

Djajanegara, A., 1983. Tinjauan ulang mengenai suplemen pada jerami padi. Kumpulan makalah seminar pemanfaatan limbah pertanian untuk makanan ternak. Lembaga Kimia Nasional dan LIPI, Bandung.

Haryanto, B., C.A.V. Lema, Yulianti, Surayah dan Abdurachman. 2004. Peningkatan degradasi serat jerami padi melalui proses fermentasi dan suplementasi zink-methionin. Proseding Seminar Nasional Teknologi Peternakan dan Veteriner, Bogor 4 - 5 Agustus 2004. Puslitbang Peternakan, Bogor. Hal. 805 - 812.

Fardiaz, S., 1992. Mikrobiologi Pangan. PT. Gramedia Pustaka Utama, Jakarta.

Judoamidjojo, M., Said, dan L. Hartoto.1989. Biokonversi. Pusat Antar Universitas. Bioteknologi. Institut Pertanian Bogor, Bogor.

Komar, A., 1984. Teknologi Pengolahan Jerami sebagai Makanan Ternak. Cetakan Pertama. Bandung. Yayasan Dian Grahita.

Leng, R. A., 1980. Principles and practices of feeding tropical crop and by products to ruminants. Development of Biochemistry and Nutrition. University of New England, Armidale, Australia.

Prasetyawan, R.M., B.I.M. Tampoebolon dan Surono., 2012. Peningkatan kualitas tongkol jagung melalui teknologi amoniasi fermentasi (AMOFER) terhadap kecernaan bahan kering dan bahan organik serta protein total secara in vitro. J. Animal Agriculture. 1 (1) :611-621.

Sofyan, Y. Oscar dan M. Amin., 2010. Pengaruh penambahan Bacillus sp. terhadap sifat fisik dan komposisi kimia jerami padi fermentasi. Laporan Penelitian. Fakultas Peternakan Unram. Mataram. 
Sundstol, E. and Owen, 1984. Straw and Fibrous by Product as Feed Development in Animal and Veterinary Sciences. Eisevier Amsterdam.

Sungkono, A., 1991. Ampas Tebu untuk Pakan Ternak. Swadaya Peternakan Indonesia. 77: 4143.

Steel, R.G.D. and J.H. Torrie. 1980. Principles and Prosedures of Statistics. Mc. Graw Hill Company Inc. New York.
Tanuwidjaja, L. 1987. The Effect of mineral salt on protein enrichment of cassava-solid- waste by solid subsrate fermentation. In:M. Soejono, A. Musofie, R. Utomo, N.K. Wardhani dan J. B. Schire (Editor). Proceeding Bioconvertion Project second Workshop on Crop Residues for Feed and Other Purposes, Grati. p:301-306.

Van Houtert, M. 1981. Some aspects of rice straw as ruminants feed in Asia. Agric. College Deventer. Netherlands. 